\title{
Exitomelita sigynae gen. et sp. nov.: a new amphipod from the Arctic Loki Castle vent field with potential gill ectosymbionts
}

\author{
Anne Helene Tandberg • Hans Tore Rapp • \\ Christoffer Schander · Wim Vader • \\ Andrew K. Sweetman · Jørgen Berge
}

Received: 18 June 2011/Revised: 6 October 2011/Accepted: 10 October 2011/Published online: 2 November 2011

(C) The Author(s) 2011. This article is published with open access at Springerlink.com

\begin{abstract}
The newly discovered deep-sea hydrothermal vent field "Loki's Castle" at 2,350 m depth at $70^{\circ} \mathrm{N}$ on the Knipovich Ridge north of the island Jan Mayen is the only known black smoker field from the Arctic Ridge system. This vent field holds a unique fauna clearly distinct from vent sites along the Mid-Atlantic Ridge south of Iceland. In addition to numerous maldanid and ampharetid polychaetes one animal of particular interest at this vent site, is a new genus and species of melitid amphipod. This new species is found in cracks and crevices on vent chimneys as well as in areas where diffuse venting is common such as the base of vent chimneys. Here, we present a formal morphological description of this new melitid species and hypothesize about the main form of its nutrition using stable isotope and molecular data.
\end{abstract}

A. H. Tandberg $(\square)$

Institute of Marine Research, PO Box 1870, Nordnes,

5817 Bergen, Norway

e-mail: AnneHelene.Tandberg@imr.no

\section{A. H. Tandberg}

International Research Institute of Stavanger,

PO Box 8046, 4068 Stavanger, Norway

\section{H. T. Rapp}

Department of Biology, University of Bergen,

Thormøhlensgate 53a, 5020 Bergen, Norway

H. T. Rapp - C. Schander - A. K. Sweetman Centre for Geobiology, University of Bergen,

Allégaten 41, 5020 Bergen, Norway

H. T. Rapp

Uni Environment, Thormøhlensgate 49B,

5020 Bergen, Norway
Keywords Vent fauna - Norwegian Sea - Melitidae . Symbioses · Arctic mid-ocean ridge - Hydrothermal vents . Stable isotopes

\section{Introduction}

Hydrothermal vent systems along mid-ocean ridges have been intensively studied for more than 30 years (e.g., Ballard 1977; Grassle et al. 1979; Hessler and Lonsdale 1991; Tunnicliffe 1991; Van Dover et al. 2002; Desbruyères et al. 2006). While hydrothermal vent systems at fast spreading ridges (e.g., The East Pacific Rise) have received the most attention so far, hydrothermal ecosystems at slow and ultra-slow spreading ridges are very poorly studied (Schander et al. 2010). The Loki's Castle

\section{Schander \\ University Museum of Bergen, PO Box 7800, \\ 5020 Bergen, Norway}

W. Vader

Troms $\varnothing$ University Museum, University of Troms $\varnothing$,

9037 Troms $\varnothing$, Norway

\section{A. K. Sweetman}

Norwegian Institute for Water Research (NIVA),

Thormøhlensgate 53D, 5006 Bergen, Norway

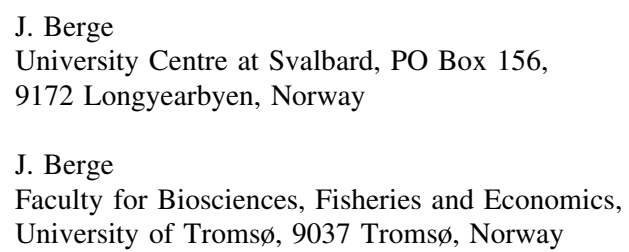


vent field at 2,350 $\mathrm{m}$ depth on the Mohn-Knipovich Ridge north of Jan Mayen in the Norwegian Sea was the first black smoker vent field to be discovered on an ultra-slow spreading ridge and the first along the Arctic ridge system (Pedersen et al. 2010). The field comprises a number of active black smoker chimneys up to $13 \mathrm{~m}$ tall at the top of an extensive mound of hydrothermal sulfide deposits. On the northeastern flank of the mound lies a sedimentary area with low-temperature diffuse venting and small barite chimneys (Pedersen et al. 2010; Kongsrud and Rapp 2011).

Earlier studies on shallow vent sites on the ridge system north of Iceland and around Jan Mayen have shown that the fauna is dominated by shallow water and bathyal species from the surrounding waters, with just a few examples of species adapted to live at hydrothermal vent systems (Fricke et al. 1989; Schander et al. 2010). Recent expeditions to study the marine biology at Loki's Castle have revealed a completely different picture of Arctic vent ecosystems with the fauna characterized by a high degree of endemism and local adaptation (Pedersen et al. 2010; Kongsrud and Rapp 2011) and reveal closer links to Pacific vent faunas compared to vent sites in the Atlantic south of Iceland (Pedersen et al. 2010).

The amphipod fauna of hydrothermal vents in the Pacific is usually dominated by scavengers such as lysianassoids (Barnard and Ingram 1990; Vinogradov 1995a, b), the swarming pardaliscid Halice hesmonectes Martin et al., 1993, and the uristid Ventiella sulfuris Barnard and Ingram, 1990 (Van Dover et al. 1992; Martin et al. 1993). In the Atlantic Ocean, the eusirids Bouvierella curtirama Bellan-Santini and Thurston, 1996 and Luckia striki Bellan-Santini and Thurston, 1996 are the only abundant and swarm-forming amphipods known from hydrothermal vents (Van Dover et al. 1992; Martin et al. 1993; Sheader et al. 2004; Bellan-Santini 2006).

Other amphipods reported in lower numbers at Atlantic vent sites include the families Amphilochidae, Stegocephalidae, Leucothoidae, Oedicerotidae, Phoxocephalidae, Pleustidae, Podoceridae, and Stenothoidae (Bellan-Santini and Thurston 1996; Bellan-Santini 2005, 2006, 2007; Schander et al. 2010). The amphipod fauna of hydrothermal vents normally does not include melitids or maerids, with the exception of Bathyceradocus wuzzae found near, but not on, the Wuzza Bare Mount vent field in the NE Pacific (Larsen and Krapp-Schickel 2007).

The amphipod family Melitidae has long been a large and unwieldy one. Records of Melitidae from abyssal and hadal depths are rare (Thurston 2000), and they are also relatively uncommon in Arctic and Antarctic waters (Jarrett and Bousfield 1996; De Broyer et al. 2007). In recent years, the Maeridae have been separated phylogenetically from the Melitidae (Krapp-Schickel 2008), and within the Melitidae s. str., several informal groups have been recognized based on morphology. The combination of an extremely reduced inner ramus and a very long outer ramus on uropod 3 (U3) distinguishes the Melita, Eriopisa, and Eriopisella groups from other Melitidae groups. Among the most abundant macroorganisms at the Loki's Castle Vent Field is a new melitid amphipod species that does not belong to any of the previously described genera. Here, we present a formal description and erect a new genus within the Melita group to encompass this new species of vent amphipod and present a hypothesis about its main form of nutrition based on morphological characters as well as molecular and stable isotope data.

\section{Materials and methods}

Melitid amphipod specimens from the Loki's Castle vent field were collected over three research cruises between 2008 and 2010 aboard the Norwegian R/V "G.O. Sars" (Fig. 1a; Table 1). Samples were collected using the "Bathysaurus" XL remotely operated vehicle (ROV) from Argus Remote Systems. Video images were acquired using a high-definition (HD) camera, and still photos were subsequently captured from the video. Fauna samples were taken both from the chimney walls as well as in sedimentary areas where diffuse venting was seen and in which dense fields of the siboglinid tube worm Sclerolinum contortum were observed. The samples were sorted on board and fixed in either $96 \%$ alcohol or $6 \%$ buffered formaldehyde in seawater. Type material has been deposited in the Natural History Collections, Bergen Museum, University of Bergen, Norway (ZMBN) (Table 1).

In the laboratory, specimens were dissected in ethanol and glycerol, and dissected mouth parts, head appendages, and additional body parts were mounted on microscope slides in Faure's medium and examined using a Leica MZ compound microscope with a drawing tube. All dissected parts were from the left side of each animal. Pencil drawings from the microscope were used as the basis for the line drawings, and were corrected, when necessary, using scanning electron microscope (SEM) images. The drawings were inked with Adobe Illustrator CS4 following Coleman (2003, 2009). Setae definitions are based on Watling (1989) and Lowry and Stoddart (1992). SEM images of gills, as well as of the morphology of mouthparts and legs were produced using a ZEISS Supra 55V SEM on pre-dissected alcohol-dried material, coated with gold/ palladium.

DNA from alcohol-preserved specimens was extracted using the FastDNA ${ }^{\circledR}$ SPIN for Soil Kit following the kit protocols. A $16 \mathrm{SrDNA}$ clone library of gill symbionts was 
Fig. 1 a Map with sampling locality. b Exitomelita sigynae crawling on the chimney of Lokis's castle. c Habitus photo of female Exitomelita sigynae G.O. Sars 2008 Dive 10-2, $35 \mathrm{~mm}$. d SEM picure of bacteria on gill of Exitomelita sigynae
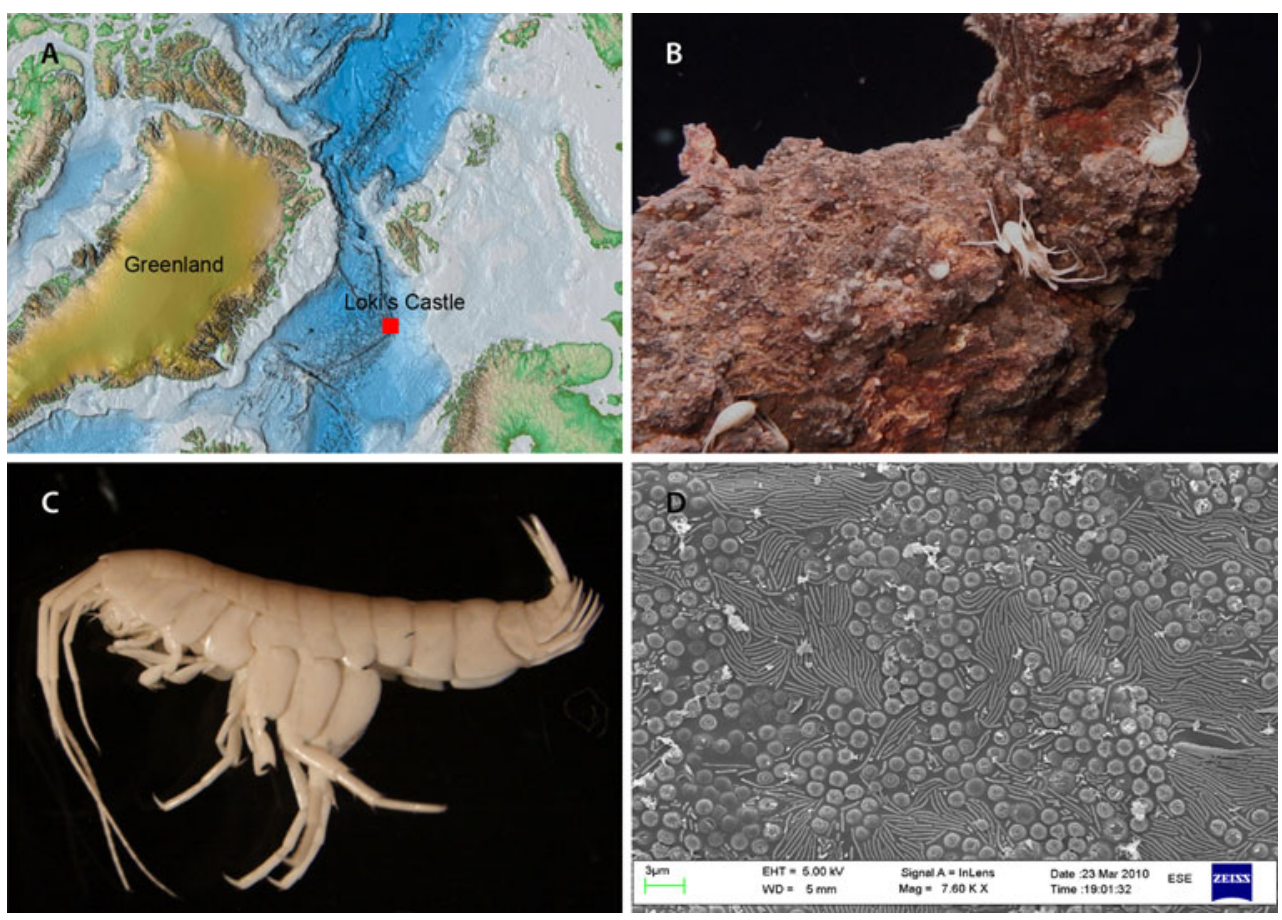

obtained using the primers B338f (Lane 1991) and B1392r (modified from Amann et al. 1995) and the Strataclone PCR Cloning Kit from Strategene. DOTUR analysis of microbial sequence data was performed to estimate the diversity of microbial gill symbionts (Schloss and Handelsman 2005). Sequences were aligned against close relatives in ARB, and maximum likelihood phylogenies were calculated in ARB. For barcoding purposes, the amphipod mitochondrial cytochrome $c$ oxidase subunit I (COI) gene (the Folmer fragment) was amplified and sequenced following standard protocols (Folmer et al. 1994).

Stable isotope analyses were performed following standard protocols as described in Levin et al. (2009) and Pedersen et al. (2010). The $\delta^{13} \mathrm{C}, \delta^{15} \mathrm{~N}$, and $\delta^{34} \mathrm{~S}$ stable isotope compositions of $E$. sigynae analyzed at the Institute for Energy Technology (IFE) at Kjeller, Norway. Approximately $1.0 \mathrm{mg}$ of material was used for the $\mathrm{C}$ and $\mathrm{N}$ analyses and $2.0 \mathrm{mg}$ for the $\mathrm{S}$ analyses. The isotopic measurements were obtained using a $\mathrm{Nu}$ Instrument Horizon, isotope ratio mass spectrometer. Results were corrected against the international standards IAEA-N-1 and IAEA-N-2 $\left({ }^{\mathrm{TM} 15} \mathrm{~N}\right)$, USGS-24 $\left({ }^{\mathrm{TM} 13} \mathrm{C}\right)$ and IAEA-S2 $\left({ }^{\mathrm{TM} 34} \mathrm{~S}\right)$.

\section{Results}

Order AMPHIPODA Latreille, 1816

Suborder GAMMARIDEA Latreille, 1803

Family MELITIDAE Bousfield, 1973
Genus Exitomelita n.gen

Type material: Holotype: ZMBN 87594. Paratypes ZMBN 87595-87597 (Table 1).

Examined material: see Table 1.

Type locality: Loki's Castle hydrothermal vent field $\left(73^{\circ} 33.9 \mathrm{~N}, 08^{\circ} 09.5 \mathrm{E}, 2,340 \mathrm{~m}\right)$.

Diagnosis: Body compressed, pereon smooth, pleon dorsally dentate. Labium with well developed inner lobes, Maxilla 1 inner plate triangular, inner margin setose. Maxilla 2 inner plate densely setose, both along inner margin and dorsal (facial). Urosome with minute dorsal teeth on urosomites 1 and 2, urosomite 2 also with small seta next to tooth. Uropod 1 peduncle with strong interramal spur. Uropod 3 outer ramus elongate, 2-articulate, inner ramus small, oval. Telson fully cleft, flappable, consisting of two oval parts. No sexual dimorphism.

Relationships: This genus belongs clearly in the Melitidae s. str. because of its strongly elongated outer ramus of uropod 3 and well-developed inner lobes of labium. The strongly inaequiramous $\mathrm{U} 3$, with the inner ramus reduced to a scale and art. 2 of the outer ramus very short, combined with a normal mandible palp and the presence of dorsal teeth on the pleon, characterizes the genus as a member of the Melita group. Jarrett and Bousfield (1996) redefined the Melita group of Barnard and Barnard (1983), but also in their definition, the Eriopisa and Eriopisella groups are still incorporated within the Melita group. The Eriopisa group has a well-developed art. 2 on the outer 


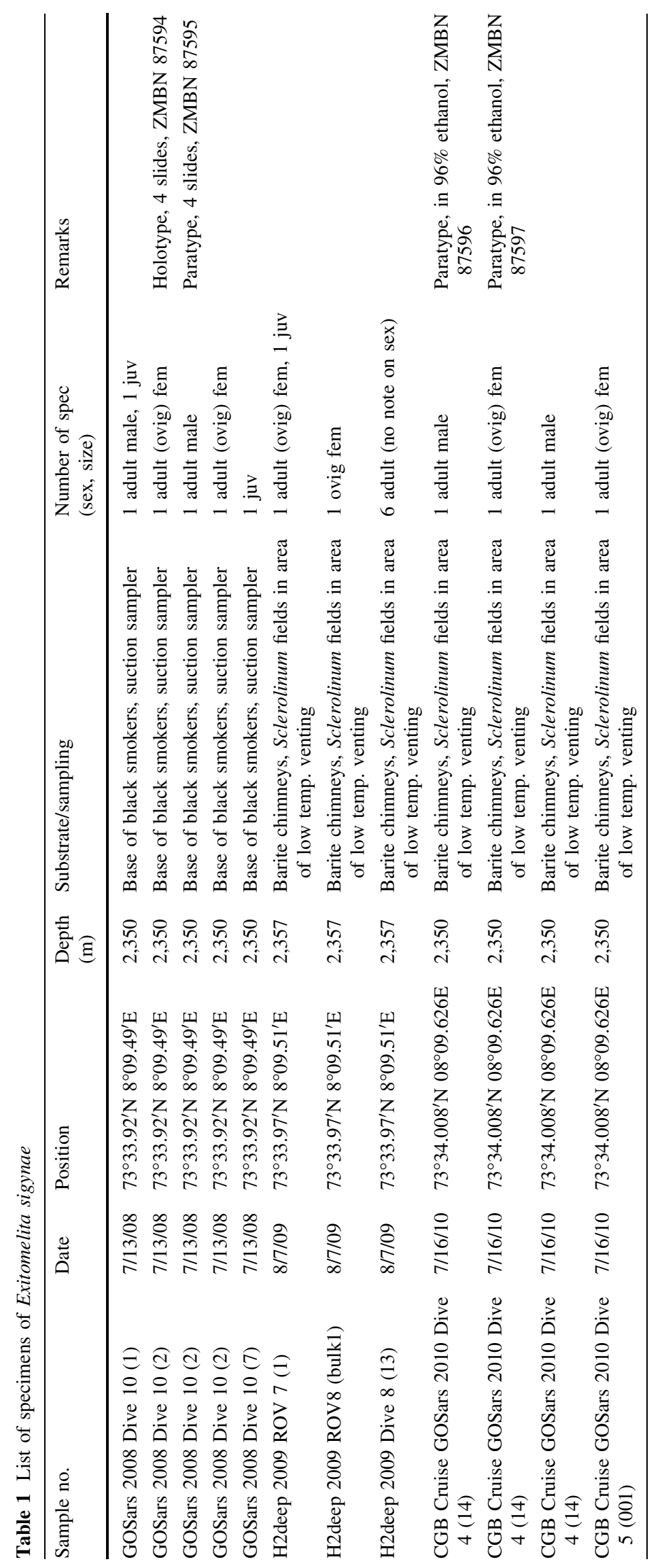


ramus of U3 and usually few or no dorsal teeth on the pleon; recent revisionary papers on this group are e.g., Karaman (1984a) and van der Ham and Vonk (2003); recent work on the Eriopisella group is by Karaman (1984b), Stock (1988), Sawicki et al. (2005), and Lowry and Springthorpe (2009).

In the key to the Melita group by Jarrett and Bousfield (1996, p. 7), Exitomelita keys out together with the Abludomelita complex. It differs, however, from Desdimelita, Melitoides, and Quasimelita by the presence of dorsal teeth on the metasome, from Megamoera, i.a., by a different telson and too few dorsal teeth, and from Abludomelita by the different proportions of pereopods 1 and 2 and the absence of sexual differentiation.

Etymology: The name Exitomelita is based on the Latin word for vent or outlet (exitus) combined with the older genus name Melita. This is because this new genus appears highly adapted and specialized to the hydrothermal vent environment, in addition to its close relation to the Melita group. The name is feminine in gender.

Exitomelita sigynae sp. nov. (Figs. 1, 2, 3, 4, 5, 6).

Type locality: Loki's Castle hydrothermal vent field (Norwegian Sea) at $73^{\circ} 33.9^{\prime} \mathrm{N}, 08^{\circ} 09.5^{\prime} \mathrm{E}, 2,340 \mathrm{~m}$.

Type material: Holotype: ZMBN 87594. Paratypes ZMBN 87595-87597 (Table 1).

Morphological description: The adult size ranges from 30 to $50 \mathrm{~mm}$. The pereon is elongate and smooth, whereas the metasome and urosome have a few teeth dorsally (Fig. 1c).

Body: All segments of approximately equal length. Normal proportions and shapes of coxae, with coxa 2 slightly overlapping coxa 1 and coxa 4 with excavate posterior margin.

Dorsal: Smooth along head and pereon, pleon with small teeth at each segment of both metasome and urosome, metasome segments 1,2, and 3 with one small tooth at each side and one small, skewed tooth (left of dorsal middle) (Fig. 5); urosome segments 1 and 2 each with two small teeth.

Head: (Figs. 1c, 5) slightly shorter than pereonites $1+2$ with a small, rounded rostrum 1/10 of head length; lateral lobe rounded, with a small notch ventrally; no apparent eyes.

Antenna 1: (Fig. 2) $80 \%$ of body length, slender; flagellum subequal to peduncle, $35-40$ articles, few very thin and short setae scattered along flagellum; peduncle article 1 double width but subequal length to article 2, article 3 half to one-third of article 2; accessory flagellum 3 -articulate.
Antenna 2: (Fig. 2) flagellum slightly shorter than peduncle, 15-20 articles, very thin setae on each article; peduncle articles 4 and 5 subequal, articles $1+2+3$ shorter than article 4 , articles 1 and 2 with protruding lobes reaching over next articles, article 5 with several thin setae spaced evenly along the article.

Mouthparts: (Fig. 1c) from lateral view forming a quadrate bundle.

Labrum: (Fig. 2) rounded, curved over front of mouthparts, ventral margin slightly notched, densely covered by minute setae.

Mandible: (Figs. 2,6) incisor crenulate and stretching in a rounded tip; lacinia mobilis on right mandible, serrate; raker setae plumose, as long as incisor; molar cylindrical triturative, chewing plate striate, accessory setae along outer margin of molar; palp 3-articulate, 3rd article rectilinear, and much thinner than articles 1 and 2, 2 simple setae at apex, the percentage of total length of the articles of the palp are $25 \%$ (article 1), 35\% (article 2), 40\% (article 3).

Labium: (Fig. 2) inner lobes small but well defined, rounded; outer lobes semi-square at distal margin.

Maxilla 1: (Figs. 2, 6) inner plate subtriangular, somewhat fleshy, lined with a row of simple setae longer toward the apex; outer plate elongate, with a crown of 13 mittenshaped cuspidate spinal-teeth; palp 2-articulate with articles subequal in length, article 2 slightly bent, and with a row of 7 nearly simple setae-all bearing one denticulation near the apex (pointed mitten-shape) and a parallel row of 10 simple setae.

Maxilla 2: (Figs. 2, 6) inner plate slightly shorter and considerably broader than outer plate, inner margin with a row of thin serrate setae, and a row of thin plumose setae (setules fairly long), tip covered with simple setae, short and thin simple facial setae at upper $20 \%$; outer plate with same rows of simple serrate and thin plumose setae, but only on the tip.

Maxilliped: (Fig. 2) compact; inner plates large, fully cleft, inner and distal margins with long plumose setae, small simple facial setae; outer plates reaching palp article 2, forming a blade-like cover behind inner plate, inner margins with a row of thick, cuspidate setae, tip with longer simple setae; palp 4-articulate, article 2 as long as articles $3+4$, article 1 short and cube-shaped; article 2 with groups of five simple setae 8 times along distal face; tip of article 3 crowned with a row of simple setae; article 4 inner margin with a line of serrate setae (Watling type 5i) (Watling 1989).

Pereon: smooth dorsally. 


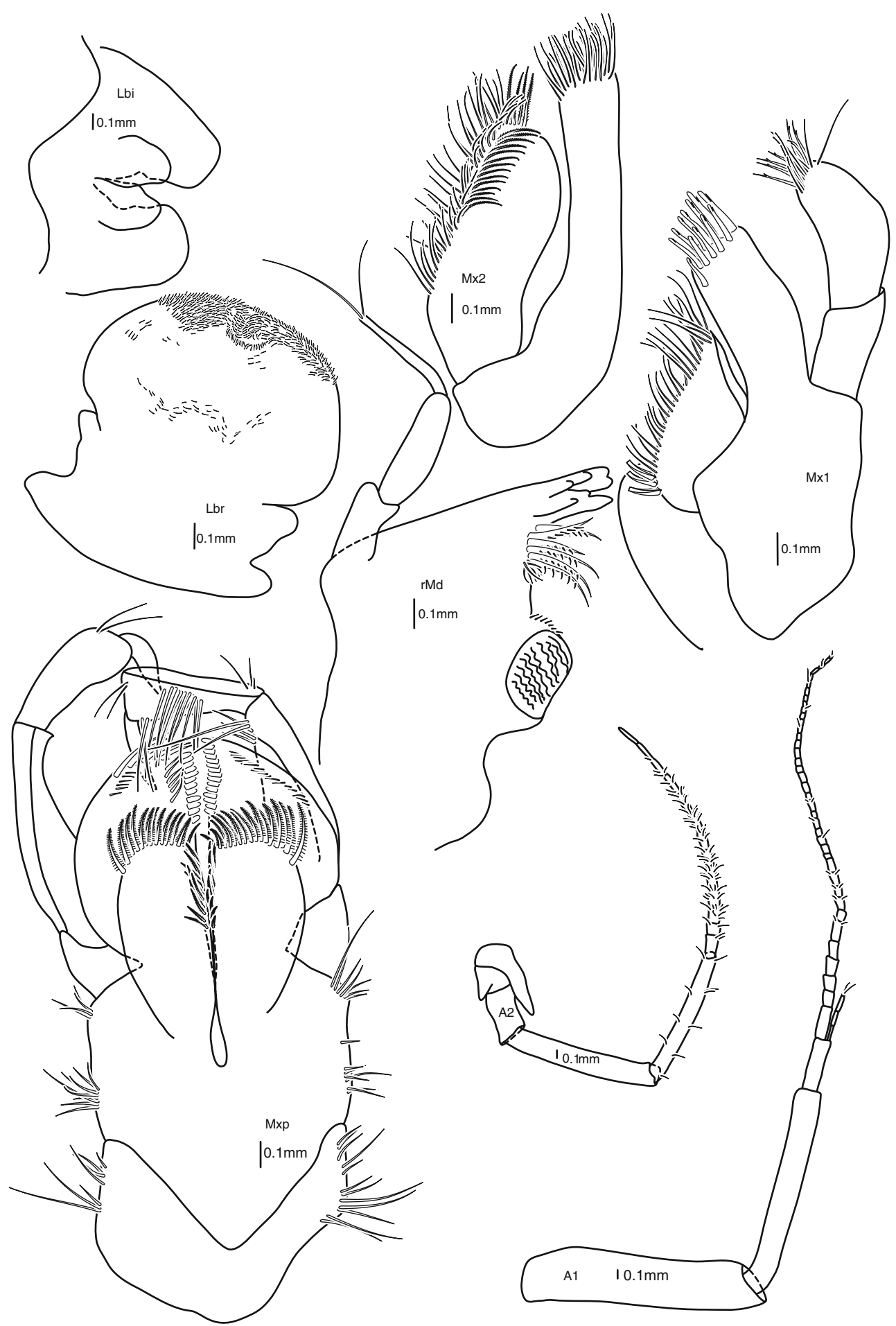

Fig. 2 Head appendages: antenna 1, antenna 2, labrum, mandible, labium, maxilla 1, maxilla 2, maxilliped. Female 39 mm (holotype). All scale bars are $0.1 \mathrm{~mm}$

Pereopod 1: (Figs. 3, 6) coxa suboval; basis straight with a few simple setae along both margins; ischium subquadrate, a row-like cluster of simple setae along posterodistal corner; merus subrectangular, posterodistal margin with a cushion of flat serrate setae, distal margin with a row of long simple setae; carpus slightly shorter than basis, subtriangular, five oblique rows grouping 6-8 long serrate setae along outer posterior margin, posterior margin cushioned in flat serrate short setae, inner posterior and anterior margins with cushions of flat serrate setae, inner distal margin with two groups of long serrate setae; propodus two-thirds of carpus length, subrectangular, with three 


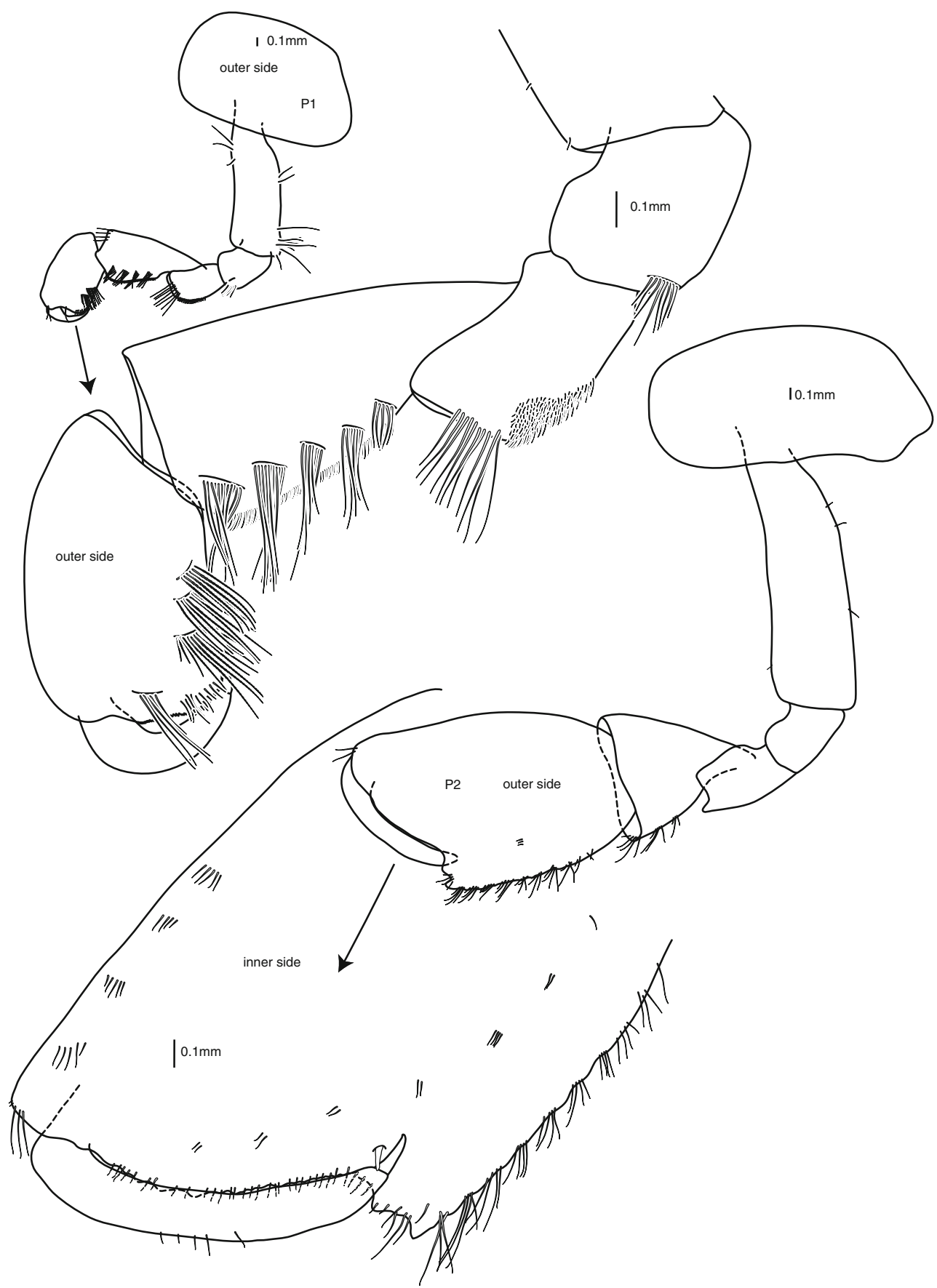

Fig. 3 Pereopods 1 and 2. Female $39 \mathrm{~mm}$ (holotype). All scale bars are $0.1 \mathrm{~mm}$

groups of 6-8 long serrate setae along outer posterior margin, a cushion of flat serrate setae reaching half of hind margin, inner anterior and posterior margins with cushions of flat serrate setae reaching half length of margins, palm minutely serrate on proximal half and with simple setae on distal half, palmar corner rounded; dactylus as long as palm, curved, smooth, with nail.

Pereopod 2: (Figs. 3, 6) coxa suboval; basis straight, longer than coxa, a few minute simple setae; ischium and merus subrectangular; carpus triangular, shorter than propodus, small patch of flat serrate setae along inner posterior margin, 3-4 groups of 4-5 long serrate setae along posterior margin; propodus subrectangular, palm oblique with palmar corner well defined by a double notch, inner face anterior margin lined with 7 groups of serrate setae, posterior margin with an elongate patch of flat serrate setae, an oblique row of setae-groups from the base of propodus to the base of dactylus, two strong cuspidate setae 


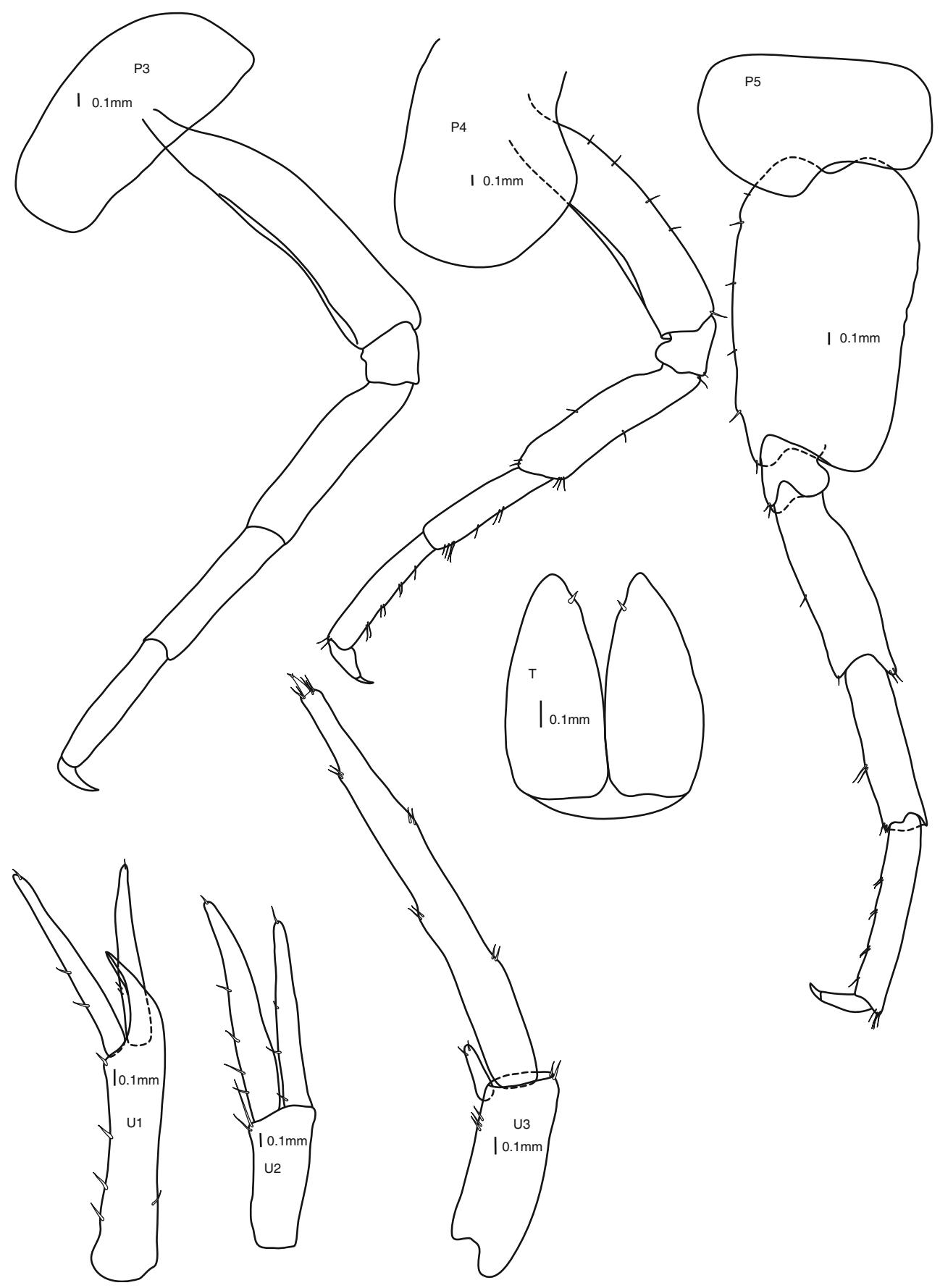

Fig. 4 Pereopods 3, 4, 5, and uropods 1, 2, 3, telson. Female $39 \mathrm{~mm}$ (holotype). All scale bars are $0.1 \mathrm{~mm}$

on inner surface near palmar corner, palm with small simple setae, outer face naked, palm with 4 small teeth outside of palmar setae; dactylus as long as oblique part of palm, curved to the inside of propodus, reaching stopping cuspidate setae, inner margin smooth, outer margin with few thin simple setae, tip of dactylus with nail.

Pereopod 3: (Fig. 4) coxa similar size as coxa 2, subrectangular; leg straight, simple and smooth; dactylus short (1/3 of propodus), with nail.
Pereopod 4: (Fig. 4) coxa as long as coxa 3, posteriorly excavate, broader than coxae 2 and 3 along distal margin; leg straight, simple and smooth, few simple setae mainly along posterior margin; dactylus short (1/3 of propodus), with nail.

Pereopod 5: (Fig. 4) basis straight, broadened, with posterior border completely smooth and posterodistal corner rounded; ischium subquadratic; merus, carpus and propodus straight and slim, approximately same length on all articles; dactylus 1/4 of propodus length, with nail. 


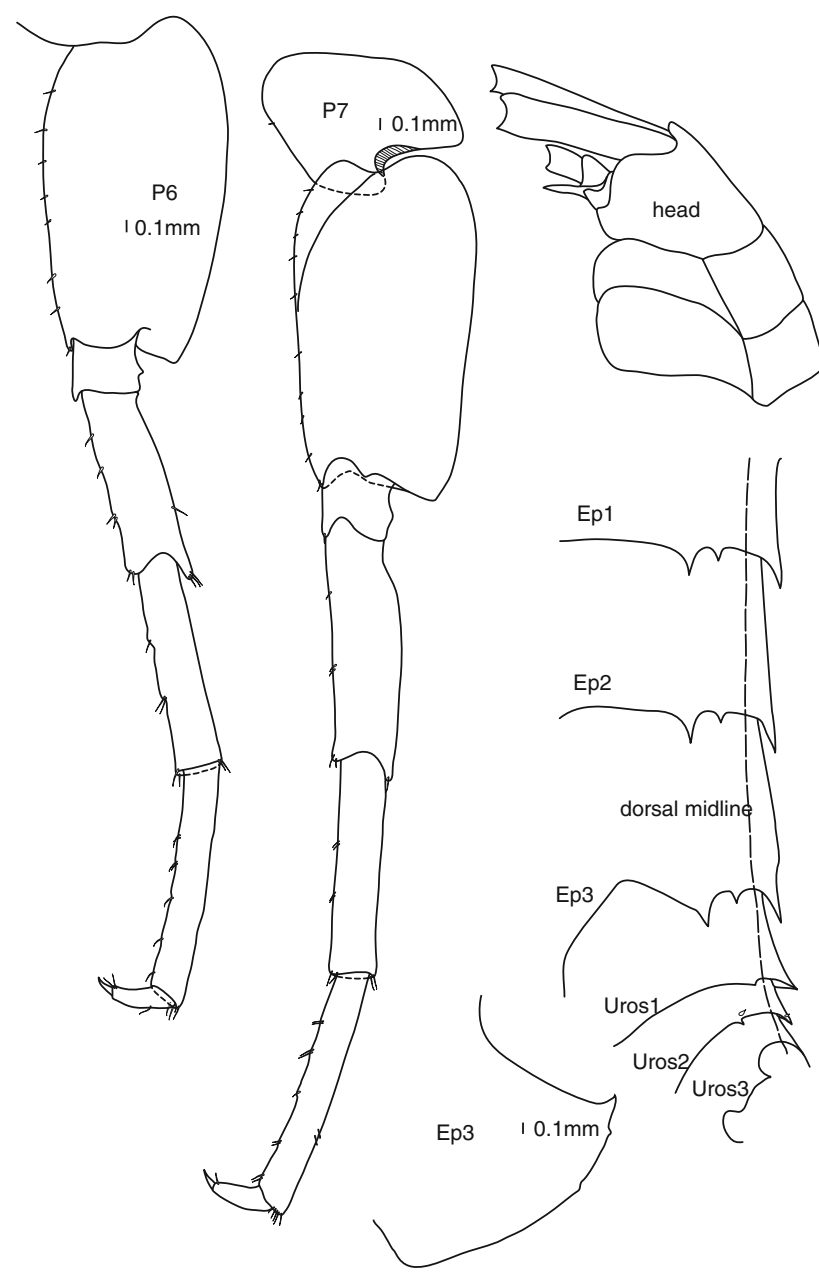

Fig. 5 Pereopods 6, 7, epimeral plate 3. Female $39 \mathrm{~mm}$ (holotype). Dorsal view of urosomal segments. Female $40 \mathrm{~mm}$ (G.O. Sars 2008 Dive 10-2). All scale bars are $0.1 \mathrm{~mm}$

Pereopods 6 and 7: (Fig. 5) coxa 6 size and shape as coxa 5, coxa 7 smaller, more pronounced bilobed; bases straight, broadened posterodistal angle sharper defined than in P5, both anterior and posterior borders slightly convex; ischia subquadratic; meri, carpi and propodi slim and elongate, length approximately $1: 1: 1$, few very short simple setae mainly along anterior margins; dactyli short (1/3 and $1 / 4$ of propodus length), both with nail.

Pleopods: Normal, no sexual dimorphism.

Epimeral plates: (Fig. 5) plate 3 with small marked upturned tooth on posterodistal corner and a few dentations along distoinferior margin.

Urosome: With small teeth on urosomite segments 1 and 2 (Figs. 5, 6).

Uropod 1: (Fig. 4) peduncle with strong and curved interramal spur; rami subequal in length, slightly longer than double length of peduncular spur, shorter than peduncle length; both peduncle and outer ramus with tiny simple setae along outer edge, both rami with a single tiny simple seta at tip.

Uropod 2: (Fig. 4) peduncle shorter than rami $(0.5 \times$ rami length); rami subequal in length (inner ramus slightly shorter), few simple setae along outer margin; uropod 2 shorter than uropod 1.

Uropod 3: (Fig. 4) peduncle shorter than peduncle of uropod 2, three tiny simple setae along outer margin; strongly elongate 2 -articulate outer ramus $(8 \times$ length of inner ramus, longer than urosome), with small simple stout setae spaced along the length of article 1, article $2 \mathrm{~min}$, barely distinguishable from the crowning setae; inner ramus short and ovoid with two tiny simple setae at tip.

Telson: (Figs. 4, 6) fully cleft, forming two ovoid parts; a small single simple strong seta at the inner distal margin of each of the parts; telson as long as peduncle of uropod 3 .

Colour of living animals: White.

Sexual dimorphism: No morphological sexual dimorphisms, but females are marginally larger than males.

Variations: The dorsal skewed third tooth on epimeral segments 1-3 can vary in how skewed from the midline it is, but was not found along the midline in any of the examined specimens.

Molecular identification: CO1 sequences (DNA-barcodes) were obtained from 2 specimens from the type locality. There was no variation between the sequences. Sequences are available in GenBank under GenBank accession numbers JN831763, JN831764 and JN831765.

Etymology: The species is named for Sigyn, the wife of the Norse god Loki, for whom the vent field (i.e., the type location) is named. Sigyn remained close to Loki during his punishment from the other gods, just as Exitomelita sigynae is closely associated with the vent field. The name is a genitive.

Ecology: E. sigynae was found crawling in cracks and crevices on the chimneys from the base of the vents up to the edge of the outlets that were venting fluids with temperatures between 310 and $320^{\circ} \mathrm{C}$. It was also found on hydrothermal sediments among dense fields of the siboglinid polychaete Sclerolinum contortum where venting was more diffuse, and the fluid temperature was much lower $\left(\sim 20^{\circ} \mathrm{C}\right)$.

Most of the examined female specimens were reproductively active carrying offspring in all developmental stages (e.g., from eggs up to ca $10 \mathrm{~mm}$ juveniles). The maximum number of eggs found on one female was 21 ; the eggs were oval in shape with diameters between $1 \mathrm{~mm}$ and 


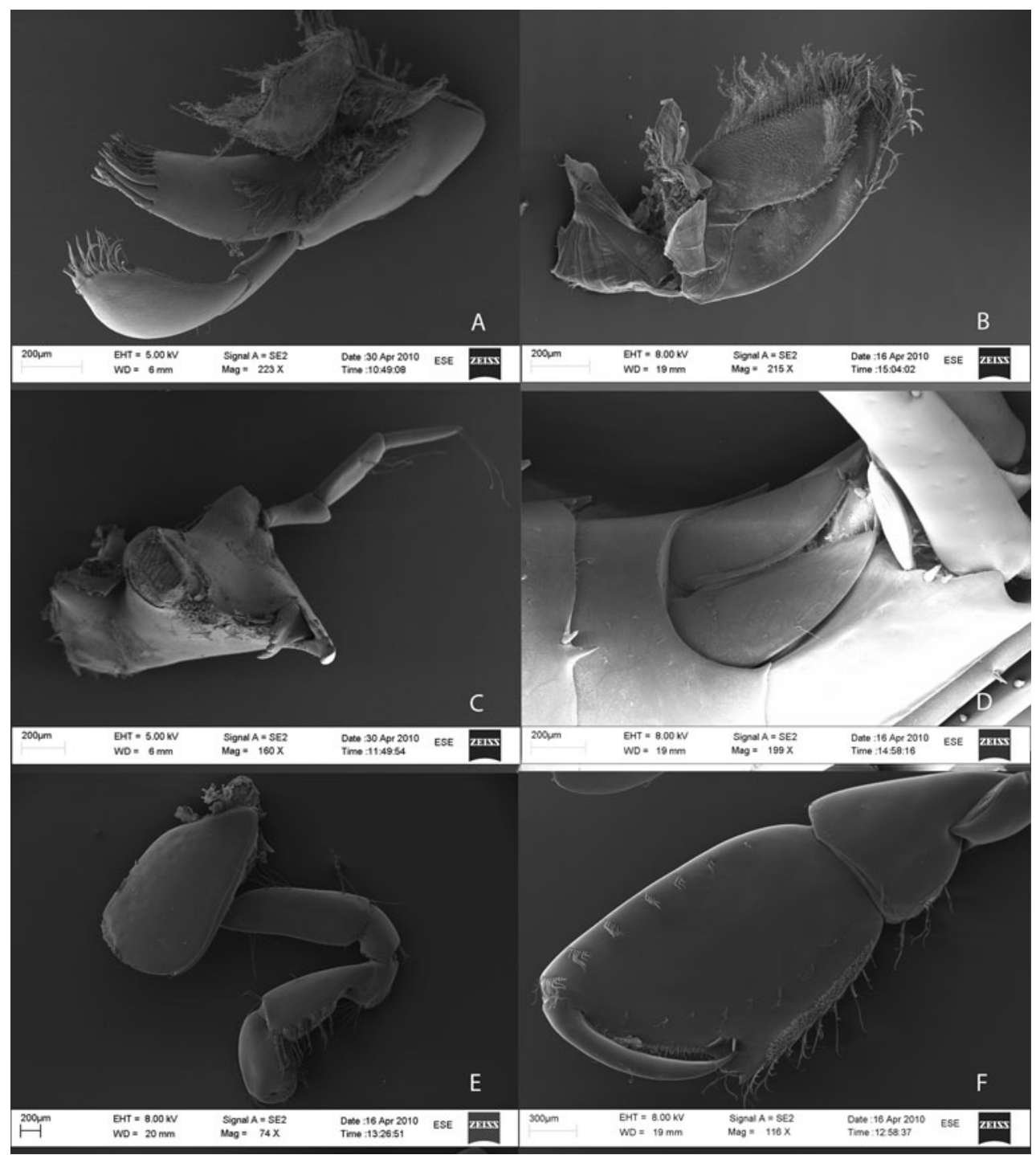

Fig. 6 SEM images of a Maxilla 1. b Maxilla 2. c Mandible. d Telson. e Pereopod 1. f Pereopod 2. Female 40 mm (G.O. Sars 2008, Dive 10-2)

$1.5 \mathrm{~mm}$. Because of the variance in developmental stages of the embryos and eggs, we conclude reproduction is continuous and/or asynchronous.

From the 16SrDNA clone library of the microbial community on the gills, a total of 90 sequences were obtained. Through DOTUR analysis, we obtained 15 OTUs with a distance level of $2 \%$. There was a pronounced dominance of two main groups of bacteria affiliated with known sulfur oxidizers found living symbiotically in the bivalves Anodontia, Idas, and Bathymodiolus, and uncultured Methylococcaceae known as methanotrophic ectosymbionts on the galatheid vent crab, Shinkaia crosnieri Baba and Williams, 1998 (both with $>98 \%$ sequence similarity). Further phylogenetic analysis using ARB confirmed these results as all sequences clustered within the Proteobacteria, and the majority $(82 \%)$ clustered within the gamma proteobacteria. Two morphotypes of bacteria were dominant on SEM images of the gill surface (Fig. 1d). Among the bacteria, there were also dense populations of a new species of ciliate from the genus Heliochona Plate, 1889 along the gill margin (Bristow et al. in preparation). Stable isotope values of $E$. sigynae were $-23.0 \%\left(\delta^{13} \mathrm{C}\right)$, $-5.9 \%$ o $\left(\delta^{15} \mathrm{~N}\right)$ and $11.9 \%$ o $\left(\delta^{34} \mathrm{~S}\right)$.

\section{Discussion}

The morphology of the mouth parts, with the mandible featuring both a highly developed incisor and a strongly triturative molar, and the abundant complex setae on both maxillae in addition to the maxilliped (Figs. 2, 6a, b) indicates that E. sigynae acts as a grazer. Abundant filamentous bacterial mats have been documented at Loki's Castle covering both chimney walls as well as most 
surfaces in the low-temperature area among dense fields of Sclerolinum tubes, suggesting a readily available source of filamentous bacteria to graze upon. A wide variety of studies at deep-sea hydrothermal vents and cold seeps have documented grazing and consumption of free-living bacteria with enriched $\delta^{13} \mathrm{C}$-signatures, as found for isotope analyses in this study (Van Dover and Fry 1994; Levin and Michener 2002; Demopoulos et al. 2010).

While the morphological results (i.e., triturative molars, setose maxillae and maxilliped) suggest that E. sigynae feeds as a grazer, the $\delta^{15} \mathrm{~N}$-signature of the specimen analyzed for isotopes was very depleted in ${ }^{15} \mathrm{~N}$ indicative of assimilation of locally fixed $\mathrm{N}$ through symbioses with endosymbionts (Conway et al. 1995). Unlike most vent organisms that rely on endosymbiotic methane- and/or sulfide-oxidizing bacteria for their nutrition (e.g., Duperron et al. 2006), E. sigynae appears to have no endosymbiotic bacteria, but appears to possess a dense layer of ectobionts embedded in the mucous layer covering the gills (Fig. 1). Although the metabolism of these microbes has not been studied in detail, their close affiliation with known sulfur and methane oxidizers as indicated from the DOTUR and ARB analysis suggests that these microbes may rely on the oxidation of ${ }^{13} \mathrm{C}$-heavy methane and/or reduced sulfur compounds. If the amphipod does derive energy from grazing and ectosymbiosis, the ectobionts would represent a rich source of nutrition indirectly enabling the amphipod to utilize the highly abundant inorganic energy sources at the Loki Castle hydrothermal vents (Pedersen et al. 2010). Although further studies need to be conducted to ascertain the reason for the very depleted $\delta^{15} \mathrm{~N}$-signature in the E. sigynae specimen analyzed, we hypothesize that the animal may derive energy through grazing and/or ectosymbiotic associations with chemosynthetic bacteria.

Vinogradov (1995b) does not include the Melitidae in the list of vent amphipods. Based on this list, E. sigynae does not seem to fit into any of the three ecological groups of vent amphipods described in Vinogradov (1995b), which include (1) compact scavengers and predators (lysianassoids) (2) bottom burrowing amphipods (ex Ampeliscidae, Corophiidae, Phoxocephalidae, Ischyroceridae), and (3) "common" mobile epibenthic animals (ex Metopa samsiluna, Seba profundis, Mesopleustes abyssorum). Since groups 2 and 3 do not include specialized amphipods (and E. sigynae shows traits to suggest that it is a specialized vent amphipod) and E. sigynae does not fit into group 1, which only includes morphologically compact amphipods like lysianassoids, there seems to be no category into which E. sigynae fits in Vinogradovs system. Another problem with Vinogradovs definitions of vent amphipods is that he views all amphipods as secondary, i.e., they do not feed directly on vent substances, but on animals that gain energy through chemosynthesis. Exitomelita sigynae appears to be a species capable of grazing at hydrothermal vents, but which may also derive energy through symbioses. If this is the case, we suggest adding a fourth group that includes "Non-compact, grazing/symbiotic amphipods". Further investigations are needed before a grazing and/or symbiotic lifestyle for E. sigynae can be confirmed. We have found a new species of amphipod and the first melitid vent amphipod from a hydrothermal vent habitat, which clearly contributes to our understanding of the diversity of amphipods associated with hydrothermal vents.

Acknowledgments We thank the crew, scientists, and students onboard the R/V G.O. Sars during the cruises 2008-2010 and the operators of the ROV Bathysaurus for their assistance at sea. RolfBirger Pedersen is especially acknowledged for his efforts coordinating the CGB field work along the Arctic midocean ridge system. Ingunn Hindenes Thorseth is thanked for making the SEM image of gill ectosymbionts, E. Erichsen for helping with the SEM work, and Solveig Hoem and Louise Lindblom (from The Biodiversity Laboratories, UoB) for performing the molecular work. This work has been supported by the NFR through Centre for Geobiology, the Norwegian Academy of Science and Letters and The Norwegian Deep Sea Program (the taxonomy fund), and by the ESF-EUROMARC program through the H2DEEP project.

Open Access This article is distributed under the terms of the Creative Commons Attribution Noncommercial License which permits any noncommercial use, distribution, and reproduction in any medium, provided the original author(s) and source are credited.

\section{References}

Amann R, Ludwig W, Schleifer KH (1995) Phylogenetic identification and in situ detection of individual microbial cells without cultivation. Microbiol Rev 59:143-169

Ballard RD (1977) Notes on a major oceanographic find. Oceanus 20:35-44

Barnard JL, Barnard CM (1983) Freshwater Amphipoda of the World. I. Evolutionary Patterns. Hayfiels Ass., Mt. Vernon, Virginia

Barnard JL, Ingram C (1990) Lysianassoid Amphipoda (Crustacea) from deep-sea thermal vents. Smiths Contr Zool 499:1-80

Bellan-Santini D (2005) Stenothoidae (Crustacea: Amphipoda) of hydrothermal vents and surroundings on the Mid-Atlantic Ridge, Azores Triple Junction Zone. J Nat Hist 39:34353452

Bellan-Santini D (2006) Arthropoda, Crustacea, Amphipoda. Handbook of deep-sea hydrothermal vent fauna. Denisia, vol 18

Bellan-Santini D (2007) New amphipods of hydrothermal vents environments on the Mid-Atlantic Ridge, Azores Triple junction zone. J Nat Hist 41(9-12):567-596

Bellan-Santini D, Thurston M (1996) Amphipoda of the hydrothermal vents along the mid-Atlantic ridge. J Nat Hist 30:685-702

Coleman CO (2003) "Digital inking": how to make perfect line drawings on computers. Org Divers Electr 3(Suppl 14):1-14

Coleman CO (2009) Drawing setae the digital way. Zoosyst Evol 85(2):305-310

Conway N, Kennicutt M, Van Dover CL (1995) Stable isotopes in the study of marine chemosynthetic based ecosystems. In: Lajtha K, Michener R (eds) Stable isotopes in ecology and environmental sciences. Blackwell, London, pp 158-186 
De Broyer C, Lowry JK, Jażdżewski K, Robert H (2007) Catalogue of the gammaridean and corophiidean Amphipoda (Crustacea) of the Southern Ocean with distribution and ecological data. In: De Broyer C (ed) Census of Antarctic marine life. Synopsis of the Amphipoda of the Southern Ocean. Institut Royal des Sciences Naturelles de Belgique, Brussels

Demopoulos AWJ, Gualtieri D, Kovacs K (2010) Food-web structure of seep sediment macrobenthos from the Gulf of Mexico. DeepSea Res II 57:1972-1981

Desbruyères D, Segonzac M, Bright M (eds) (2006) Handbook of the Deep-Sea hydrothermal vent fauna, 2 nd edn. Denisia 18 , State Museum of Upper Austria

Duperron S, Bergin C, Zielinski F, Blazejak A, Pernthaler A, McKiness ZP, DeChaine E, Cavanaugh CM, Dubilier N (2006) A dual symbiosis shared by two mussel species, Bathymodiolus azoricus and Bathymodiolus puteoserpentis (Bivalvia: Mytilidae), from hydrothermal vents along the northern Mid-Atlantic Ridge. Environ Microbiol 8:1441-1447

Folmer O, Black M, Hoeh W, Lutz R, Vrijenhoek R (1994) DNA primers for amplification of mitochondrial cytochrome $c$ oxidase subunit I from diverse metazoan invertebrates. Mol Mar Biol Biotechnol 3(5):294-299

Fricke H, Giere O, Stetter K, Alfredsson GA, Kristjansson JK, Stoffers P, Svavarsson J (1989) Hydrothermal vent communities at the shallow subpolar Mid-Atlantic Ridge. Mar Biol 102:425-429

Grassle JF, Berg CJ, Childress JJ, Grassle JP, Hessler RR, Jannasch H, Karl DM, Lutz RA, Mickel TJ, Rhoads DC, Sanders HL, Smith KL, Somero GN, Turner RD, Tuttle JH, Walsh PJ, Williams AJ (1979) Galapagos '79: Initial findings of a deep-sea biological quest. Oceanus 22:2-10

Hessler RR, Lonsdale PF (1991) Biogeography of Mariana Trough hydrothermal vent communities. Deep-Sea Res 38:185-199

Jarrett NE, Bousfield EL (1996) The amphipod superfamily Hadzioidea on the Pacific Coast of North America: family Melitidae. Part I. The Melita group: systematics and distributional ecology. Amphipacifica II 2:3-74

Karaman GS (1984a) Revision of Eriopisa-complex of genera (Gammaridea) (Contribution to the knowledge of the Amphipoda 139). Poljoprivreda i Sumarstvo 30:39-72

Karaman GS (1984b) Contribution to the knowledge of the Amphipoda 141. Quadrus vagabundus, new genus and species, and revision of genus Eriopisella Chevr. (Gammaridea). Studia Marina Kotor 15-16:131-148

Kongsrud JA, Rapp HT (2011) Nicomache (Loxochona) lokii sp. nov. (Annelida: Polychaeta: Maldanidae) from the Loki's Castle vent field-an important structure builder in an Arctic vent system. Pol Biol. doi:10.1007/s00300-011-1048-4

Krapp-Schickel T (2008) What has happened with the Maera-clade (Crustacea, Amphipoda) during the last decades? Boll Mus Civ Stor Nat Verona 32:3-32

Lane DJ (1991) 16S/23S rRNA sequencing. In: Stackenbrandt E, Goodfellow M (eds) Nucleic Acid Techniques in Bacterial Systematics. John Wiley, New York, pp 115-148

Larsen K, Krapp-Schickel T (2007) Amphipoda (Crustacea: Peracarida) from chemically reduced habitats; the hydrothermal vent system of the north-east Pacific. Part II. Melitidae and Eusiridae. J Mar Biol Ass UK 87:1207-1217

Levin LA, Michener R (2002) Isotopic evidence of ectosynthesisbased nutrition of macrobenthos: the lightness of being at Pacific methane seeps. Limnol Oceanogr 47:1336-1345

Levin LA, Mendoza GF, Kontchick T, Lee R (2009) Macrobenthos community structure and trophic relationships within active and inactive Pacific hydrothermal sediments. Deep-Sea Res II 57:632-1648

Lowry JK, Springthorpe RT (2009) Melitidae, the Melita group. Zootaxa 2260:718-735

Lowry JK, Stoddart HE (1992) A revision of the genus Ichnopus (Crustacea: Amphipoda: Lysianassoidea: Uristidae). Rec Austr Mus 44:185-245

Martin JW, France SC, VanDover CL (1993) Halice hesmonectes, a new species of pardaliscid amphipod (Crustacea, Peracarida) from hydrothermal vents in the eastern Pacific. Can J Zool 71:1724-1732

Pedersen RB, Rapp HT, Thorseth IH, Lilley M, Barriga F, Baumberger T, Flesland K, Bernasconi-Green G, Flesland K, Jørgensen SL (2010) Discovery of a black smoker field and vent fauna at the Arctic Mid-Ocean Ridge. Nat Commun 1:126. doi: $10.1038 /$ ncomms 1124

Sawicki TR, Holsinger JR, Iliffe TM (2005) New species of amphipod crustaceans in the genera Tegano and Melita (Hadzioidea. Melitidae) from subterranean groundwaters in Guam, Palau, and the Philippines. J Crust Biol 25:49-74

Schander C, Rapp HT, Kongsrud JA, Bakken T, Berge J, Cochrane S, Oug E, Byrkjedal I, Cedhagen T, Fosshagen A, Gebruk A, Larsen K, Nygren A, Obst M, Pleijel F, Stöhr S, Todt C, Warén A, Handler-Jacobsen S, Kuening R, Levin L, Mikkelsen NT, Petersen KK, Thorseth IH, Pedersen RB (2010) The fauna of the hydrothermal vents on the Mohn Ridge (North Atlantic). Mar Biol Res 6(2):155-171

Schloss PD, Handelsman J (2005) Introducing DOTUR, a computer program for defining operational taxonomic units and estimating species richness. Appl Environ Microbiol 71(3):1501-1506

Sheader M, Van Dover CL, Thurston MH (2004) Reproductive ecology of Bouvierella curtirama (Amphipoda: Eusiridae) from chemically distinct vents in the Lucky Strike vent field, MidAtlantic Ridge. Mar Biol 144:503-514

Stock JH (1988) Two new stygobiont Amphipoda (Crustacea) from Polynesia. Stygologia 4:79-100

Thurston M (2000) Benthic Gammaridea (Crustacea: Amphipoda) in the deep sea. Pols Arch Hydrobiol 47:353-377

Tunnicliffe V (1991) The biology of hydrothermal vents: ecology and evolution. Oceanogr Marine Biol Annu Rev 29:319-407

van der Ham J, Vonk R (2003) A phylogenetic analysis of the Eriopisa complex (Crustacea: Amphipoda: Melitidae) and a new species from beach interstitia in Venezuela. J Nat Hist 37:779-796

Van Dover CL, Fry B (1994) Microorganisms as food resources at deep-sea hydrothermal vents. Limnol Oceanogr 39:51-57

Van Dover CL, Kaartvedt S, Bollens SM, Wiebe PH, Martin JW, France SC (1992) Deep-sea amphipod swarms. Nature 358:25-26

Van Dover CL, German CR, Speer KG, Parson LM, Vrijenhoek RC (2002) Evolution and biogeography of deep-sea vent and seep invertebrates. Science 295:1253-1257

Vinogradov GM (1995a) Amphipods from hydrothermal vents and seep fields of the ocean. Okeanologiya 35:71-85 (in Russian)

Vinogradov GM (1995b) Colonization of pelagic and hydrothermal vent habitats by Gammaridean Amphipods: an attempt at reconstruction. Pol Arch Hydrobiol 42:417-430

Watling L (1989) A classification system for crustacean setae based on the homology concept. In: Felgenhauer BE, Watling L, Thistle AB (eds) Functional morphology of feeding and grooming in crustacea. AA Balkema, Rotterdam, pp 15-26 